Prepared in cooperation with the

Florida Fish and Wildlife Conservation Commission

\title{
Composition of Age-0 Fish Assemblages in the Apalachicola River, River Styx, and Battle Bend, Florida
}

Open-File Report 2009-1145

U.S. Department of the Interior

U.S. Geological Survey 